УДК 517.9

\title{
Spectra of Effective Permeability and Losses of Magnetic Composite Films
}

\author{
Leonid N. Kotov* \\ Ekaterina G. Kurdyukova \\ Institute of Exact Sciences and Information Technology \\ Syktyvkar State University \\ Oktyabrsky, 55, Syktyvkar, 167001 \\ Russia \\ Yurii E. Kalinin \\ Aleksander V.Sitnikov \\ Voronezh State Technical University \\ Moscow Avenue, 14, Voronezh, 394026
}

Russia

Received 20.08.2016, received in revised form 03.12.2016, accepted 26.02.2017

The research was devoted to a studying of the spectra effective permeability and losses in the magnetic composite films at different ratios of concentrations of metal and dielectric. The effective permeability was determined from the ratio of capacitance of the capacitor with a film (magnetic metal-dielectric) and without film. The results the permeability spectra for films for different composition and concentration of metals and dielectrics showed that they had similar trend of behavior in general.

Keywords: spectra,effective and dielectric permeability, losses, magnetic composite films, quasiplasma, eddy currents.

DOI: $10.17516 / 1997-1397-2017-10-2-248-251$.

\section{Introduction}

The research was devoted to a studying of the spectra effective permeability and losses in composite films. It was a theoretical part in the work about studying and creation of RF recording and processing devices, which was based on composite films. The fact that the effective permeability of the film, which conswasts from nanogranular of metal and dielectric, depended from the concentration of positive ions and free electrons, and the frequency of collwasions of electrons with spatial in homogeneities and the boundaries between the dielectric and metal beads. If the frequency of the external AC field $f$ was equal to the natural frequency of the electronic quasiplasma $f_{e}$ then effective permittivity of metal-dielectric composite film was decreased. Consequently a frequency behavior of electric polarization vector in a dielectric environment in the middle of metal might have an anomalous character. On the basis of such anomalies might be created metal-dielectric composite films, necessary for the technical implementations.

${ }^{*}$ kotovln@syktsu.ru

(C) Siberian Federal University. All rights reserved 


\section{Research subject}

We had conducted research of frequency dependences of real and imaginary parts of dielectric permittivity (dielectric spectra), and loss tangent of composite films for different metals and dielectrics. However, we received the effective spectrum, which greatly influenced the current in the metal granules. The effective spectra were obtained under different ratios of concentrations of metal $M e$ and dielectric $D$ phases in the composite films. Targets from metallic alloys $M e$ (CoFeZr, CoFeB, CoTaNb, Co) and dielectrics $D\left(\mathrm{Al}_{2} \mathrm{O}_{3}, \mathrm{SiO}_{2}, \mathrm{Zr}_{2} \mathrm{O}_{3}, \mathrm{Zr}_{2} \mathrm{O}\right)$ was used for the production of films [1,2]. Deposition of films was carried out using ion bombardment of targets on PET substrate. The thickness of the films was $0.3 \div 1.5 \mathrm{mkm}$. Measure dielectric permittivity were performed on the values of inductance, capacitance and quality factor $Q$ of the serial resonant circuit at room temperature in the frequency range $f=30 \div 300 \mathrm{MHz}$. The results of dielectric spectra for films for different composition and concentration of metals and dielectrics showed that they had similar trend of behavior in general. The composition and concentration of metal and dielectric phases of the films were next:

Series 801: $\left(\mathrm{CoFeZr}_{0.3}\right)_{x}\left(\mathrm{Al}_{2} \mathrm{O}_{3}\right)_{y}$

Series 802: $\left(\mathrm{Co}_{45} \mathrm{Fe}_{45} \mathrm{Zr}_{10} \mathrm{O}_{a}\right)_{x}\left(\mathrm{Al}_{2} \mathrm{O}_{3}\right)_{1-x}, \quad 1<a<10$

Series 803: $\left(\mathrm{Co}_{45} \mathrm{Fe}_{45} \mathrm{Zr}_{10}\right)_{x}(\mathrm{CaF})_{1-x}$

Concentration of metallic phase varies: $0.22<x<0.8$

Concentration of dielectric phase varies: $0.22<y<0.8$

\section{Research method}

Inductor $L$ and capacitor $C$ were connected to terminals of the device. The tested composite film was placed between the capacitor plates. The resonance condition for an oscillating circuit current was satisfied. We took reading a quality factor $Q$ and capacitance of the measuring capacitor $C$. These steps were repeated at each frequency for each film in the frequency range $f=30 \div 300 \mathrm{MHz}$. The air losses were exclude from our calculation for each investigated range measuring were carried out for capacitor $C$ without samples, too. Then obtained losses tangent values of empty capacitor were subtracted from one with the samples. After experiments we had 3 parameters sets: $Q$ factor, capacitance $C$ and frequencies $f$. The first dependences which we found for all films were films loss tangent. The necessary experiment parameter was a film $Q$ factor. To find the only film $Q$ factor we subtracted from $Q$ factor of capacitor with sample empty capacitor $Q$ factor. To calculate the loss tangent we used formula:

$$
\tan \delta_{f}=\tan \delta_{c+f}-\tan \delta_{c}=\frac{1}{Q_{c+f}}-\frac{1}{Q_{c}} .
$$

Next we found films permeability dependences using formula:

$$
\varepsilon=\frac{C d_{0}}{\varepsilon_{0} S}
$$

\section{Results}

We could note that losses tangent growth in films series 803 began from low metal phase concentration than series 801 and 802. It happened because films of 803 series had greater 
dielectric conductivity than films others series (higher on 2 and 4 order for magnitude) (Fig. 1). If tell about higher frequencies range for 801 series (Fig. 2), we could see that there was sharp

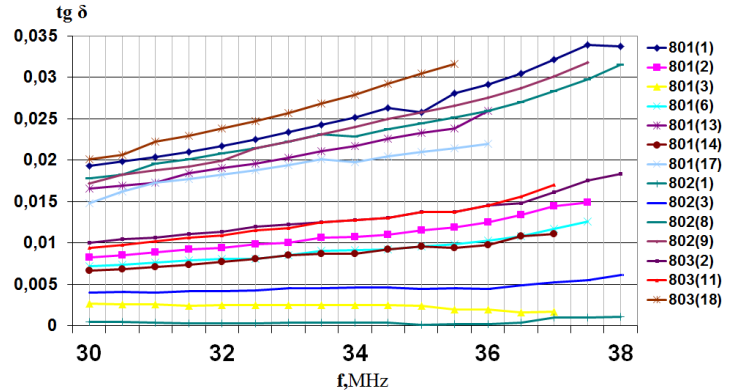

Fig. 1. Loss tangent of the dielectric permeability in the frequency range $30-38 \mathrm{MHz}$

increase. It was connected with narrow range of the percolation threshold. For 802 and 803 the percolation region was "blurred" and sharp increasing were observed only for large metal phase concentration (Fig. 3). From Fig. 4 it was clear that the permeability decreased with increasing

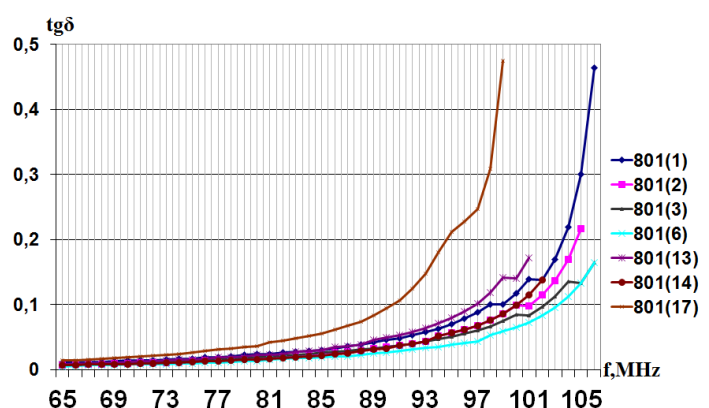

Fig. 2. Loss tangent of the dielectric permeability in the frequency range $65-108 \mathrm{MHz}$ for series 801

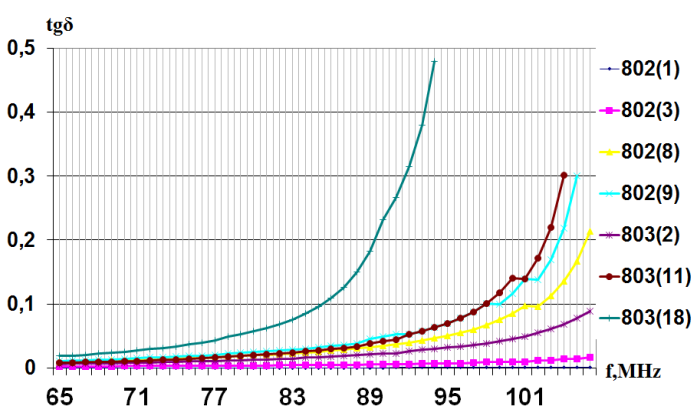

Fig. 3. Loss tangent of the dielectric permeability in the frequency range $65-108 \mathrm{MHz}$ for series 802 and 803

frequencies for different metal phase concentration on different frequencies. This behavior was

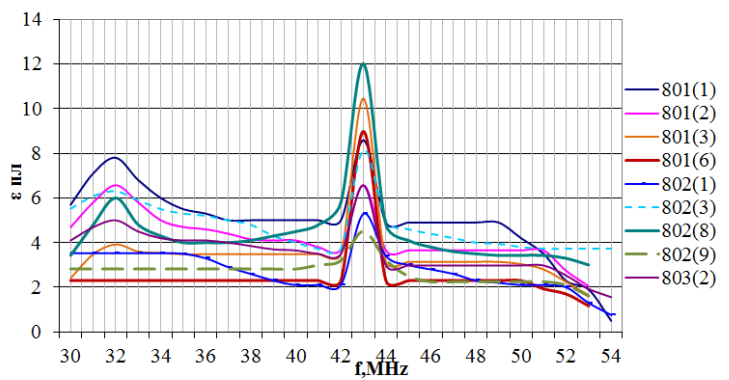

Fig. 4. Dielectric permeability of the composite films in the frequency range $30-54 \mathrm{MHz}$

explained by relaxation of the dielectric polarization. The reason was in a decrease of electric fields in these frequencies. The permeability values for different concentration were determined 
by volume relative of dielectric and metal phases. Eddy currents determine the basic loss at high frequencies [3].

\title{
Conclusion
}

For all test's films loss tangent increased with increasing concentration of the metal phase. This was due to the Joule-Lenz formula for the power losses. Growth start was determined by the appearance of the percolation process or metal particles group. Eddy currents determine the basic loss at high frequencies and the imaginary component of permeability. The amplitude of these currents depends on the aspect ratio of micro- and nanogranul and the mean free path of the electrons, and the magnetic permeability of the composite films granules.

The work performed in part under financial support Minwastry of Education and Science of Russian Federation, project no. 1503.

\section{References}

[1] I.V.Antonets, L.N.Kotov, Yu.E.Kalinin, A.V.Sitnikov, V.G.Shavrov, V.I.Sheglov, Technical Physics Letters, 40(2014), no. 7, 584-586.

[2] L.N.Kotov, V.K.Turkov, V.S.Vlasov, Yu.E.Kalinin, A.V.Sitnikov, F.F.Asadullin, JMMM, 316(2007), e20-e223.

[3] L.V.Lutsev, N.T.Kazantseva, I.A.Tchmutin, N.G.Rynkina, Yu.E.Kalinin, A.V.Sitnikoff, J. Physics: Cond. Matter, 14(2002), 1-15.

\section{Спектры эффективной проницаемости и потерь в магнитных композитных пленках}

\author{
Леонид Н. Котов \\ Екатерина Г. Курдюкова \\ Институт точных наук и информационных технологий \\ Сыктывкарский государственный университет \\ Октябрьский пр., 55, Сыктывкар, 167001 \\ Россия \\ Юрий Е. Калинин \\ Александр В. Ситников \\ Воронежский государственный технический университет \\ Московский пр., 14, Воронеж, 394026 \\ Россия
}

Исследование посвящено изучению спектров эффективной пронищаемости и потерь в магнитных композитных пленках при различных соотношениях концентраций металлической и диэлектрической фаз. Эффективная проницаемость определяется из соотношения емкости конденсатора с пленкой (магнитный металл-диэлектрик) и без пленки. В резулътате спектры проницаемости для пленок различного состава и кониентрачий металлов и диэлектриков показали, что они в иелом имеют подобные тендениии в поведение.

Ключевые слова: спектр, эффективная и диэлектрическая проницаемость, потери, магнитные композитные пленки, вихревые токи, квазиплазма. 